\title{
Problems of Development and Integration of the Securities Market in the Countries of the EAEU ${ }^{1}$
}

\author{
A. Bayadyan, A. Baghdasaryan
}

Ashot Bayadyan - Doctor, Professor, Head of the Chair of Finance and Credit, Economic Department, National Agrarian University of Armenia; 74, Teryan St., Yerevan 0009, Republic of Armenia; E-mail: info@anau.am

Areg Baghdasaryan - PhD, Associate Professor, Chair of Finance and Credit, Economic Department, National Agrarian University of Armenia; 74, Teryan St., Yerevan 0009, Republic of Armenia; E-mail: aregbag@gmail.com

The article is devoted to studying problems associated with the development and integration of the securities market in the countries of the Eurasian Economic Union. The article examines the present state, possibilities and problems pertaining to the development of the securities market and, in particular, the regulated market. The development and integration of the securities market is an important factor affecting the potential for economic development and sustainable economic growth in the countries of the Eurasian Economic Union. The subject of this study is the development and integration problems affecting the securities market in the countries of the Eurasian Economic Union.

The securities market in the countries of the Eurasian Economic Union has sufficient integration opportunities. Potential exists in all segments of the securities market, but more opportunities exist in the debt securities market. The deepening of the integration processes in the securities market of the countries of the Eurasian Economic Union could have a positive impact on increasing the investment opportunities of the economies of these countries. This, in turn, can have a positive impact on the growth of the gross domestic product, reducing unemployment and improving the social status of the population. However, the creation of a single or integrated exchange market should be accompanied by the integration of depository processes as well as the settlement and clearing systems, and the synchronizing of the regulatory and legal framework governing the securities market. Particular attention is required to study the problems associated with fixing and transferring property rights to the securities and protecting the interests of investors. The integration processes of depository, settlement and clearing systems may include the introduction of a nominee holder for central depositories and the establishment of correspondent relations between the central depositories of the securities of the countries of the Eurasian Economic Union. For the development of integration processes both in the regulated market and between depository, settlement and clearing systems, the most important prerequisite is synchronization and, in the future, will be the unification of the regulatory and legal framework governing the securities market.

Key words: the securities market, regulated market, infrastructures of the securities market

For citation: Bayadyan A., Baghdasaryan A. (2017) Problems of Development and Integration of the Securities Market in the Countries of the EAEU. International Organisations Research Journal, vol. 12, no 4, pp. 91-108 (in Russian and English). DOI: 10.17323/1996-7845-2017-04-91

${ }^{1}$ The editorial board received the article in September 2017. 
The development of the securities market is an important factor affecting the potential for economic development and sustainable economic growth in the EAEU countries. After the collapse of the Soviet Union and the transition to a market economy in the post-Soviet space, disparate financial markets were formed. This disparity is especially evident in the securities market. The problems of the disparity of the securities market are also exacerbated by the presence of significant differences in the regulation of the securities market among countries in the region, the principles of building a depository, settlement and clearing systems, as well as fixing and transferring proprietary rights and other property rights to the securities.

A rather large number of studies have been devoted to the analysis of the problems affecting the development of the securities market in the EAEU countries over the past twenty-five years. In most studies, the problems associated with the development of the securities markets are addressed by individual countries within the EAEU. Some studies help address the development of individual segments or functions of the securities market.

The investment functions of the securities market have been studied in detail. They address the peculiarities and problems facing the financing of investments through securities market instruments [Salnazaryan, 2003; Karev, 2012; Semernina, 2012], the development trends of individual and institutional investment in the securities market [Korneev, 2007; Statsenko, 2012], issues related to the issuance and placement of securities [Glushetsky, 2012; Gevorgyan, 2013], organizational and methodological issues surrounding the securitization process and its role in financing investment projects [Tereshchenko, 2011; Pavelieva, 2013], as well as problems of increasing the effectiveness of corporate governance [Margaryan, 2013]. Issues concerning the formation and development of trading, depository and settlement systems in the securities market [Mirkin, 1995; Zakharov et al, 2002; Puchkov, 2003], as well as questions about the modernization of the securities market's infrastructure [Shalisco, 2013] were studied intensively. The problems affecting the formation of the securities market in post-socialist countries [Kozlov, 2002], and problems stemming from crises on the securities market [Stanik, 2013] are considered. The problems associated with the development of the securities market were mainly considered in the context of accelerating economic growth [Mirkin, 2002; Dementyev, 2009; Bessarabova, 2013], as well as from the point of view of the development of certain segments of the securities market [Kiselev, 2010], regional markets [Miller, 2013] or market development in foreign countries [Kudinova, 2005; Vakhrushin, 2009]. The problems associated with the regulation of the securities market were considered mainly in the context of the regulation of the entire financial system [Tsarikhin, 2008; Fabozzi et al., 2009; Bolonin, 2010; Rzhevskaya, 2012], as well as from the point of view of self-regulation mechanisms in financial markets [Ilyin, 2012] and the regulation of the services of professional securities market entities [Vilkova, 2007; Gorlovskaya, 2010]. In recent years, intense research has been carried out in the field of development of integration processes in the securities market [Rubtsov, 2000; Fedorova, 2011], particularly from the point of view of formation of the Com- 
mon Economic Space of the Russian Federation, Belarus and Kazakhstan [Ilyas, 2012; Niyazbekova, 2014].

However, the study of the problems affecting the development and integration of the securities market cannot be limited to the study of only one or several market segments. It is also important to study the problems associated with development and the integration of settlement, clearing and depository systems in comparison with problems related to development and integration in the exchange market. In light of the possibilities associated with creating a common economic space, a comprehensive study of the prospects for the integration of the securities market of the EAEU countries becomes particularly important.

The purpose of this study is to develop recommendations for the development and integration of the stock markets of the EAEU countries. Based on the research objectives, the article examines the present state and peculiarities of the development of the securities market in the EAEU countries, as well as the opportunities and prospects for the integration of the securities market in the EAEU countries.

After the collapse of the USSR, the development and integration of the securities market in the post-Soviet space was primarily attempted at the national level. This stage, in most of the EAEU countries, can be considered already completed. Thus, if at the end of the last millennium there were four stock exchanges on the territory of the Republic of Armenia, at present there is only one stock exchange - NASDAQ OMX Armenia. ${ }^{2}$ Integration processes were also initiated in the field of depository and settlement-clearing systems. Currently, the introduction of a single depositary and settlement and clearing system is in its final stage, which is also the structural division of NASDAQ OMX [Baghdasaryan, 2013, pp. 167-177]. Similar trends have been observed in the Russian market. Thus, at the end of 2011 there was the merger of two main trading systems in the Russian securities market - RTS and MICEX ${ }^{3}$. As a result of the merger, the Moscow Exchange was formed - the largest securities market trading system in the post-Soviet space. Integration processes also took place in the sphere of depository, settlement and clearing systems operating on the territory of the Russian Federation. As part of the Moscow Exchange group, a company was formed that provides all types of depository and settlement services on the securities market. This company - the National Settlement Depository, was given the status of a central depository in 2012. ${ }^{4}$ In accordance with the legislation of the Russian Federation, the status of a central depository can be assigned to only one legal entity. Thus, both in the Republic of Armenia and in the Russian Federation, integrated trading, depositary and settlement-clearing systems have been formed in the securities market [Baghdasaryan, 2012, p. 10]. Similar trends have been observed in other EAEU countries.

The processes leading to the further integration of the securities market are related to the integration of national trading, depository, settlement and clearing systems operating in different countries. Such integration processes can include the creation and strengthening of links between national systems, the synchronization of the regulatory

${ }^{2}$ NASDAQ OMX Armenia. Available at: http://www.nasdaqomx.am.

${ }^{3}$ Moscow Exchange (MICEX-RTS). Available at: http://www.moex.com.

${ }^{4}$ National Settlement Depository. Available at: http://www.nsd.ru. 
framework, regulating the securities market, and the formation of supranational systems. In the sphere of international integration, different countries in the post-Soviet space began to adhere to different priorities. In the Baltic region, for example, the integration processes were mainly aimed at synchronizing national legislation with the legislation of the European Union. In these countries, both regulated securities market operators and settlement system operators (central securities depositories) are part of the Nasdaq group [Baghdasaryan, 2013, p. 189]. A unified trading system has been established in the Baltic region. The central depositories of securities of Lithuania, Latvia and Estonia have links between themselves, through which ownership and other property rights are recorded; these also perform the function of a settlement system. There is also the integration of the Nasdaq Baltic securities market with other Nasdaq markets, particularly with the Nordic market. Correspondent relations with depository, settlement and clearing systems operating in the territory of the European Union, such as Clearstream or Euroclear, have been formed. International integration processes are also deepening in the territory of the EEA countries. Significant integration opportunities exist in the securities market of the Russian Federation, Belarus and Kazakhstan.

One of the aspects of the integration processes of the securities market occurring within the EAEU is the unification of stock exchanges, as well as depository, settlement and clearing systems, through the acquisition of participation (shares) and (or) reorganization. In this vein, integration processes take place on the exchange market of the Moscow Exchange.

Another goal of the integration processes of the securities market within the EAEU countries is to develop cooperation between the operators of the aforementioned exchanges and related depository, settlement and clearing systems. This aspect of the integration processes is observed in the relations between the Moscow Exchange, the Belarusian Currency and Stock Exchange and the Kazakhstan Stock Exchange. ${ }^{5},{ }^{6},{ }^{7}$

Especially important is the development of integration processes between the Russian and Armenian stock markets. The importance of such integration is due to the fact that on the one hand, the main securities exchange operating on the territory of the Russian Federation, the Moscow Exchange, is the initiator of integration processes with securities exchanges operating on the territory of the Republic of Belarus and the Republic of Kazakhstan, the Belarusian Currency and Stock Exchange and the Kazakhstan Stock Exchange; while on the other hand, the only stock exchange operating on the territory of the Republic of Armenia, NASDAQ OMX Armenia, is already tied to one of the leading operators of exchange market, depository, settlement and clearing systems in the world; one it shares with the three Baltic countries - the Nasdaq group [Baghdasaryan, 2013, p. 189]. Thus, the development of such integration processes can become the starting point for the development of integration processes between the systems operating in the territory of the European Union and the Eurasian Economic Union. However, the creation of unified and integrated systems in the exchange market also implies the integration of depository, settlement and clearing systems, as well

\footnotetext{
${ }^{5}$ Belarusian Currency and Stock Exchange. Available at: http://www.bcse.by.

${ }^{6}$ Kazakhstan Stock Exchange. Available at: http://www.kase.kz.

${ }^{7}$ Moscow Exchange (MICEX-RTS). Available at: http://www.moex.com.
} 
as the synchronization of the regulatory and legal framework governing the securities market. In particular, special attention needs to be given to the study of problems related to fixing and transferring property rights to securities and protecting the interests of investors.

In order to disclose the integration opportunities of the securities market, it is also important to study the basic indicators of the exchange market, taking into account the peculiarities of the development of the securities market in the territory of the EAEU. We've selected the number of issuers whose shares are admitted to trading on the exchange market, the market capitalization of shares admitted to trading on the exchange market, the volume of trading in shares and debt securities, as well as the volume of trade in currency and credit resources on the exchange market.

The number of issuers whose shares are admitted to trading on the exchange market in the EAEU countries is shown in Table 1.

Table 1. The number of issuers whose shares are admitted to trading on the exchange market in the EAEU countries, 2011-2015

\begin{tabular}{|l|c|c|c|c|c|}
\hline \multirow{2}{*}{ Country } & \multicolumn{5}{|c|}{ Number of issuers whose shares are admitted to trading on the exchange } \\
& \multicolumn{7}{|c|}{ market } \\
\cline { 2 - 6 } & $\mathbf{2 0 1 1}$ & $\mathbf{2 0 1 2}$ & $\mathbf{2 0 1 3}$ & $\mathbf{2 0 1 4}$ & $\mathbf{2 0 1 5}$ \\
\hline Armenia & 11 & 11 & 11 & 11 & 10 \\
\hline Belarus & 2,335 & 2,359 & 67 & 67 & 62 \\
\hline Kazakhstan & 71 & 81 & 80 & 77 & 85 \\
\hline Kyrgyzstan & 13 & 18 & 20 & 21 & 23 \\
\hline Russian Federation & 341 & 271 & 284 & 281 & 254 \\
\hline
\end{tabular}

Source: compiled by the authors on the basis of exchange statistics of the countries of the EAEU $^{8,9,10}$

Table 1 shows that the Russian Federation is in first place among the countries of the EAEU in terms of the number of companies listing shares on the local exchange market. In 2015, the shares of 254 issuers were traded via Russia's Moscow Exchange. The Republic of Kazakhstan and the Republic of Belarus are in second and third place among the EAEU countries in terms of the number of issuers whose shares are traded on the local exchange market. The number of listed shares in these countries, however, is much less than in the Russian Federation. In 2015, the shares of 85 and 62 issuers were listed, respectively, in the Republic of Kazakhstan and the Republic of Belarus. The smallest number of issuers whose shares are traded on the local exchange market are registered in the Kyrgyz Republic and the Republic of Armenia - 23 and 10, respectively.

\footnotetext{
${ }^{8}$ Bulletins of stock exchange statistics: 2006-2014, International Association of Exchanges of the CIS Countries. Available at: http://mab.micex.ru.

${ }^{9}$ Directories of stock exchanges and depositaries - members of the IAE CIS. 2006-2015, International Association of Exchanges of the CIS Countries. Available at: http://mab.micex.ru.

${ }^{10}$ FEAS Books: 2009-2015, Federation of Euro-Asian Stock Exchanges. Available at: http://www.feas.org.
} 
The market capitalization of shares traded on the local exchange markets in the EAEU countries is presented in Table 2.

Table 2. Exchange capitalization of the stock market in EAEU countries, 2011-2015

\begin{tabular}{|l|c|c|c|c|c|}
\hline \multirow{2}{*}{ Country } & \multicolumn{5}{|c|}{ Exchange capitalization of the stock market, billion US dollars } \\
\cline { 2 - 6 } & $\mathbf{2 0 1 1}$ & $\mathbf{2 0 1 2}$ & $\mathbf{2 0 1 3}$ & $\mathbf{2 0 1 4}$ & $\mathbf{2 0 1 5}$ \\
\hline Armenia & 0.1 & 0.1 & 0.2 & 0.2 & 0.2 \\
\hline Belarus & 1.1 & 0.4 & 3.7 & 0.6 & 0.5 \\
\hline Kazakhstan & 22.6 & 23.5 & 26.3 & 23.0 & 34.9 \\
\hline Kyrgyzstan & 0.2 & 0.2 & 0.2 & 0.2 & 0.2 \\
\hline Russian Federation & 771.2 & 827.3 & 776.3 & 409.2 & 393.2 \\
\hline
\end{tabular}

Source: compiled by the authors on the basis of exchange statistics of the countries of the EAEU $^{11,12,13}$

As can be seen from Table 2, the Russian Federation is in first place among the EAEU countries in terms of stock market capitalization. In the Russian Federation, stock market capitalization amounted to 393.2 billion US dollars in 2015. Second place in terms of stock market capitalization is held by the Republic of Kazakhstan. In the other EAEU countries, stock market capitalization is significantly less than in the Russian Federation or the Republic of Kazakhstan. Exchange capitalization of the equity market in 2015 in the Republic of Kazakhstan was 34.9 billion US dollars, in the Republic of Belarus it was 0.5 billion US dollars, and in the Republic of Armenia and the Kyrgyz Republic it was 0.2 billion US dollars.

The significant difference between the number of issuers whose shares are admitted to trading on the exchange market and the stock market capitalization in the EAEU countries is due to the specifics of regulation of the securities market and the volume of the economy in the respective EAEU countries. Thus, if the Russian Federation has 25 times as many issuers as Armenia whose shares are listed on the country's exchange market, then its volume of exchange capitalization totals almost 2,000 times.

Volumes of stock trading on the exchange market in the EAEC countries are presented in Table 3.

Table 3 shows that the Russian Federation is first among the EAEU countries in terms of equity market trading volume. In the Russian Federation, equity trading volume amounted to about 139.2 billion US dollars in 2015. The Republic of Kazakhstan demonstrated the second highest volume of equity market trading. In the rest of the EAEU countries, the volume of equity market trading is significantly less than in the Russian Federation and the Republic of Kazakhstan. The volume of equity market trading in 2015 in the Republic of Kazakhstan amounted to almost 4 billion dollars, whereas

\footnotetext{
${ }^{11}$ Bulletins of stock exchange statistics: 2006-2014, International Association of Exchanges of the CIS Countries. Available at: http://mab.micex.ru.

${ }^{12}$ Directories of stock exchanges and depositaries - members of the IAE CIS. 2006-2015, International Association of Exchanges of the CIS Countries. Available at: http://mab.micex.ru.

${ }^{13}$ FEAS Books: 2009 - 2015, Federation of Euro-Asian Stock Exchanges. Available at: http://www.feas.org.
} 
in the Republic of Armenia this figure was 9.1 million dollars; in the Republic of Belarus it was 8.3 million dollars and in the Kyrgyz Republic it was 17.5 million dollars.

Table 3. The volume of stock trading on the exchange market in the EAEU countries, 2011-2015

\begin{tabular}{|l|c|c|c|c|c|}
\hline \multirow{2}{*}{ Country } & \multicolumn{5}{|c|}{ Volume of trade in shares, mln. USD } \\
\cline { 2 - 6 } & $\mathbf{2 0 1 1}$ & $\mathbf{2 0 1 2}$ & $\mathbf{2 0 1 3}$ & $\mathbf{2 0 1 4}$ & $\mathbf{2 0 1 5}$ \\
\hline Armenia & 0.5 & 1.0 & 3.7 & 60.6 & 9.1 \\
\hline Belarus & 50.4 & 90.0 & 57.3 & 46.6 & 8.3 \\
\hline Kazakhstan & $1,089.2$ & $1,377.6$ & 783.6 & 961.1 & $3,956.2$ \\
\hline Kyrgyzstan & 28.0 & 22.5 & 24.7 & 21.6 & 17.5 \\
\hline Russian Federation & $554,067.3$ & $372,619.7$ & $266,894.9$ & $263,180.9$ & $139,167.2$ \\
\hline
\end{tabular}

Source: compiled by the authors on the basis of exchange statistics of the countries of the EAEU ${ }^{14,15,16}$

The volumes of trade in debt securities on the exchange market in the EAEU countries are presented in Table 4.

As Table 4 illustrates, the Russian Federation holds first place among the EAEU countries in terms of the volume of trade in debt securities on the exchange market. In the Russian Federation, the volume of debt market trading in 2015 amounted to about 116.6 billion US dollars. The Republic of Kazakhstan and the Republic of Belarus witnessed the second and third largest annual volumes of debt market trading in that year (4.9 and 4.5 billion US dollars, respectively). The volume of debt market trading is significantly less in the Republic of Armenia (29.8 million US dollars). The smallest amount of market trading in debt securities was in the Kyrgyz Republic (5.1 million US dollars).

The disproportionate development of the securities market and, especially, the stock market in the EAEU countries is due to various factors, both objective and subjective in nature. The objective factors include the differences in the size of the countries' respective economies and the market volumes in the different countries of the EAEU. These differences, in turn, affect a number of other differences, such as differences in market competition, market liquidity and pricing in the market. In addition, there are a number of factors of a subjective nature that affect the securities market, primarily the stock market. Such factors include differences in the culture of corporate governance and public administration, the degree of protection of investors' rights and interests and the stability of the political situation in the country.

One of the main prerequisites for the development of integration processes in the market is the "existence" of this market. The stock market in some EAEU countries

\footnotetext{
${ }^{14}$ Bulletins of stock exchange statistics: 2006-2014, International Association of Exchanges of the CIS Countries. Available at: http://mab.micex.ru.

${ }^{15}$ Directories of stock exchanges and depositaries - members of the IAE CIS. 2006-2015, International Association of Exchanges of the CIS Countries. Available at: http://mab.micex.ru.

${ }^{16}$ FEAS Books: 2009-2015, Federation of Euro-Asian Stock Exchanges. Available at: http://www.feas.org.
} 
Table 4. The volume of trade in debt securities on the exchange market in the EAEU countries, 2011-2015

\begin{tabular}{|l|c|c|c|c|c|}
\hline \multirow{2}{*}{\multicolumn{1}{|c|}{ Country }} & \multicolumn{5}{|c|}{ Volume of trade in debt securities, mln. USD } \\
\cline { 2 - 6 } & $\mathbf{2 0 1 1}$ & $\mathbf{2 0 1 2}$ & $\mathbf{2 0 1 3}$ & $\mathbf{2 0 1 4}$ & $\mathbf{2 0 1 5}$ \\
\hline Armenia & 15.7 & 11.4 & 44.3 & 82.7 & 29.8 \\
\hline Belarus & $2,280.5$ & $4,707.5$ & $3,928.4$ & $5,541.7$ & $4,520.1$ \\
\hline Kazakhstan & $9,762.5$ & $3,712.9$ & $4,044.9$ & $8,421.8$ & $4,910.2$ \\
\hline Kyrgyzstan & 1.3 & 2.1 & 5.4 & 5.3 & 5.1 \\
\hline Russian Federation & $1,627,303.9$ & $2,246,430.0$ & $396,993.3$ & $225,841.2$ & $116,564.7$ \\
\hline
\end{tabular}

Source: compiled by the authors on the basis of exchange statistics of the countries of the EAEU $^{17,18,19}$

is almost non-existent, there are no liquid market instruments, there are no pricing mechanisms, there is no quotation, there is no interest in the market among potential issuers and investors, and there are no effective mechanisms for protecting the rights and interests of shareholders. From the data shown in Tables 3-4, it can be seen that the debt securities market, unlike the equity market, is developed to a certain extent in almost all EAEU countries. This circumstance indicates that the integration opportunities of the debt securities market are largely higher than the integration opportunities of the stock market. In addition, the development of integration processes in the debt securities market is less dependent on the differences in the culture of corporate governance. Therefore, special attention should be given to the development of integration processes in this market. To identify the integration opportunities of certain segments of the debt securities market, it is important to study the indicators of the volume of trade in corporate debt securities and government securities. The market for government securities is the most promising segment of the market from the point of view of the development of integration processes. This is due to the fact that sovereign debt is among the most reliable financial instruments in the EAEU countries. Equally important is the fact that EAEU countries have similar principles with respect to public administration and the servicing of public debt.

The volume of trade in corporate debt securities on the exchange market in the EAEU countries is presented in Table 5.

Table 5 shows that the Russian Federation occupies the first place among the EAEU countries by the volume of trade in corporate debt securities on the exchange market. The volume of trade in corporate debt securities on the exchange market in 2015 amounted to about 60.7 billion US dollars in the Russian Federation. Second and third places in terms of the volume of exchange-based corporate debt trading were held by Kazakhstan and Belarus (3.5 and 2 billion dollars, respectively). The volume of

${ }^{17}$ Bulletins of stock exchange statistics: 2006-2014. International Association of Exchanges of the CIS Countries, Available at: http://mab.micex.ru.

${ }^{18}$ Directories of stock exchanges and depositaries - members of the IAE CIS. 2006-2015. International Association of Exchanges of the CIS Countries. Available at: http://mab.micex.ru.

${ }^{19}$ FEAS Books: 2009-2015. Federation of Euro-Asian Stock Exchanges. Available at: http://www.feas.org. 
exchange-based corporate debt trading in 2015 was significantly smaller in Kyrgyzstan (5.1 million dollars). The smallest volume of debt securities trading on the exchange market was recorded in Armenia (4.4 million dollars).

Table 5. The volume of trade in corporate debt securities on the exchange market in the EEA countries, 2011-2015

\begin{tabular}{|l|c|c|c|c|c|}
\hline \multirow{2}{*}{\multicolumn{1}{|c|}{ Country }} & \multicolumn{5}{|c|}{ Volume of trade in corporate debt securities, mln. USD } \\
\cline { 2 - 6 } & $\mathbf{2 0 1 1}$ & $\mathbf{2 0 1 2}$ & $\mathbf{2 0 1 3}$ & $\mathbf{2 0 1 4}$ & $\mathbf{2 0 1 5}$ \\
\hline Armenia & 1.8 & 1.0 & 7.1 & 11.2 & 4.4 \\
\hline Belarus & $1,150.8$ & $1,138.6$ & $1,930.4$ & $2,392.7$ & $2,020.1$ \\
\hline Kazakhstan & $2,010.8$ & $2,165.3$ & $2,789.9$ & $2,708.8$ & $3,532.8$ \\
\hline Kyrgyzstan & 1.3 & 2.1 & 5.4 & 5.3 & 5.1 \\
\hline Russian Federation & $1,225,153.2$ & $1,848,335.6$ & $193,921.9$ & $112,782.5$ & $60,742.7$ \\
\hline
\end{tabular}

Source: compiled by the authors on the basis of exchange statistics of the countries of the EAEU $^{20,21,22}$

The volume of exchange-based sovereign debt trading in the EAEU countries is presented in Table 6.

As can be seen from Table 6, the Russian Federation far outpaces its EAEU peers in terms of the volume of sovereign debt traded locally on the exchange market. The volume of sovereign debt traded on the national securities exchange in 2015 amounted to about 54.3 billion US dollars. Belarus and Kazakhstan place second and third in terms of the volume of trade in government securities on the exchange market (2.5 and 1.3 billion dollars, respectively). The volume of sovereign debt trading is significantly smaller in Armenia (25.4 million dollars). In Kyrgyzstan, government securities are not traded on the exchange market at all.

From the data shown in Tables 5 and 6, it can be seen that the corporate securities market is the most developed in the Russian Federation and at its least developed in Armenia and Kyrgyzstan. In Armenia, the majority of instruments traded in the securities market are government securities. This is due to both the low level of corporate governance development and the structure of investors in the securities market. One of the main groups of investors in the securities market are banks that require reliable, highly liquid instruments with low credit risk for repo transactions with the Central Bank of the Republic of Armenia. A similar situation is also observed in other countries of the EAEU. However, in these countries, along with the development of the government securities market, we can see also some development of the corporate securities market. The development of integration processes in the securities market can help spread the positive experience between the EAEU countries.

${ }^{20}$ Bulletins of stock exchange statistics: 2006-2014, International Association of Exchanges of the CIS Countries. Available at: http://mab.micex.ru.

${ }^{21}$ Directories of stock exchanges and depositaries - members of the IAE CIS. 2006-2015, International Association of Exchanges of the CIS Countries. Available at: http://mab.micex.ru.

${ }^{22}$ FEAS Books: 2009-2015, Federation of Euro-Asian Stock Exchanges. Available at: http://www.feas.org. 
Table 6. The volume of exchange-based sovereign debt trading in the EAEU countries, 2011-2015

\begin{tabular}{|l|c|c|c|c|c|}
\hline \multirow{2}{*}{\multicolumn{1}{|c|}{ Country }} & \multicolumn{5}{|c|}{ Volume of trade in government securities, mln. USD } \\
\cline { 2 - 6 } & $\mathbf{2 0 1 1}$ & $\mathbf{2 0 1 2}$ & $\mathbf{2 0 1 3}$ & $\mathbf{2 0 1 4}$ & $\mathbf{2 0 1 5}$ \\
\hline Armenia & 13.9 & 10.4 & 37.2 & 71.5 & 25.4 \\
\hline Belarus & $1,129.7$ & $3,516.0$ & $1,918.8$ & $3,141.2$ & $2,500.0$ \\
\hline Kazakhstan & $7,751.7$ & $1,547.6$ & $1,255.0$ & $5,711.1$ & 126.4 \\
\hline Kyrgyzstan & 0 & 0 & 0 & 0 & 0 \\
\hline Russian Federation & $402,149.8$ & $398,094.7$ & $188,611.1$ & $103,233.8$ & $54,272.9$ \\
\hline
\end{tabular}

Source: compiled by the authors on the basis of exchange statistics of the countries of the EAEU $^{23,24,25}$

The volume of foreign currency trading on the exchange market in the EAEU countries is presented in Table 7.

Table 7. The volume of foreign currency trading on the exchange market in the EAEU countries, 2011-2015

\begin{tabular}{|l|c|c|c|c|c|}
\hline \multirow{2}{*}{\multicolumn{1}{|c|}{ Country }} & \multicolumn{5}{|c|}{ Foreign currency trading volume, mln. USD } \\
\cline { 2 - 6 } & $\mathbf{2 0 1 1}$ & $\mathbf{2 0 1 2}$ & $\mathbf{2 0 1 3}$ & $\mathbf{2 0 1 4}$ & $\mathbf{2 0 1 5}$ \\
\hline Armenia & 760.4 & 753.7 & 714.5 & 744.5 & 313.7 \\
\hline Belarus & $17,002.5$ & $30,047.8$ & $31,771.3$ & $30,044.3$ & $30,012.1$ \\
\hline Kazakhstan & $106,179.9$ & $96,063.7$ & $120,583.0$ & $188,295.8$ & $190,034.1$ \\
\hline Kyrgyzstan & 0 & 0 & 0 & 0 & 0 \\
\hline Russian Federation & $2,938,156.7$ & $3,760,597.0$ & $4,878,451.6$ & $5,979,928.8$ & $5,980,024.1$ \\
\hline
\end{tabular}

Source: compiled by the authors on the basis of exchange statistics of the countries of the EAEU $^{26,27,28}$

Table 7 shows that the Russian Federation holds first place among the EAEU countries in terms of foreign currency trading on its local exchange market. The volume of foreign currency trading on Russia's exchange market in 2015 amounted to about 6 trillion US dollars. Kazakhstan holds second place in terms of the volume of foreign currency trading on its exchange market; in 2015 it amounted to 190 billion USD. In the rest of the EAEU countries, the volume of foreign currency trading on the local exchange market is significantly less than in the Russian Federation and the Republic

${ }^{23}$ Bulletins of stock exchange statistics: 2006-2014, International Association of Exchanges of the CIS Countries. Available at: http://mab.micex.ru.

${ }^{24}$ Directories of stock exchanges and depositaries - members of the IAE CIS. 2006-2015, International Association of Exchanges of the CIS Countries. Available at: http://mab.micex.ru.

${ }^{25}$ FEAS Books: 2009-2015, Federation of Euro-Asian Stock Exchanges. Available at: http://www.feas.org.

${ }^{26}$ Bulletins of stock exchange statistics: 2006-2014, International Association of Exchanges of the CIS Countries. Available at: http://mab.micex.ru.

${ }^{27}$ Directories of stock exchanges and depositaries - members of the IAE CIS. 2006-2015, International Association of Exchanges of the CIS Countries. Available at: http://mab.micex.ru.

${ }^{28}$ FEAS Books: 2009-2015, Federation of Euro-Asian Stock Exchanges. Available at: http://www.feas.org. 
of Kazakhstan. The volume of foreign currency trading on the exchange market in 2015 in the Republic of Belarus totaled 30 billion US, and in the Republic of Armenia this figure was only 313.7 million USD. Foreign currency trading is not conducted at all on the local exchange market in Kyrgyzstan.

The volume of trade in credit resources on the exchange market in the EAEU countries is presented in Table 8.

- As can be seen from Table 8, trade in credit resources on the exchange market in the EAEU countries has been conducted only in the Russian Federation and the Republic of Armenia. However, the volume of trade in credit resources in these countries is not remotely comparable. In 2015, the volume of trade in credit resources on the exchange market amounted to about 559 billion US dollars in the Russian Federation, while in the Republic of Armenia this figure was only to 92 million US dollars. It should also be noted that as a result of changes in the terms of trade in credit resources on the exchange market in the Republic of Armenia, trade in credit resources has not actually been conducted since September 2015.

Table 8. The volume of trade in credit resources on the exchange market in the EAEU countries, 2011-2015

\begin{tabular}{|l|c|c|c|c|c|}
\hline \multirow{2}{*}{\multicolumn{1}{|c|}{ Country }} & \multicolumn{5}{|c|}{ Volume of trade in credit resources, mln. USD } \\
\cline { 2 - 6 } & $\mathbf{2 0 1 1}$ & $\mathbf{2 0 1 2}$ & $\mathbf{2 0 1 3}$ & $\mathbf{2 0 1 4}$ & $\mathbf{2 0 1 5}$ \\
\hline Armenia & $7,087.7$ & $15,084.3$ & $16,444.1$ & 657.1 & 92.1 \\
\hline Belarus & 0 & 0 & 0 & 0 & 0 \\
\hline Kazakhstan & 0 & 0 & 0 & 0 & 0 \\
\hline Kyrgyzstan & 0 & 0 & 0 & 0 & 0 \\
\hline Russian Federation & $339,180.5$ & $349,846.6$ & $478,106.2$ & $558,646.1$ & $559,100.3$ \\
\hline
\end{tabular}

Source: compiled by the authors on the basis of exchange statistics of the countries of the EAEU $^{29},{ }^{30},{ }^{31}$

From the data presented above, it can be seen that the development of the exchange market in a particular region largely depends on the size of the market and the extent of integration in the market. Thus, the Russian Federation, which has the largest and most sufficiently integrated exchange market among the EAEU countries, is the leader in all key indicators. From the point of view of the development of small markets, such as the Armenian securities market, integration with other domestic markets, for example, with the foreign exchange market and the market for credit resources, is of great importance. Such integration can yield a synergistic effect. In countries with small markets, the creation of integrated systems increases the efficiency of their activities, which, in turn, allows stock exchanges to invest additional funds in the development of trading, depository, clearing and settlement systems. The creation of integrated

${ }^{29}$ Bulletins of stock exchange statistics: 2006-2014, International Association of Exchanges of the CIS Countries. Available at: http://mab.micex.ru.

${ }^{30}$ Directories of stock exchanges and depositaries - members of the IAE CIS. 2006-2015, International Association of Exchanges of the CIS Countries. Available at: http://mab.micex.ru.

${ }^{31}$ FEAS Books: 2009-2015, Federation of Euro-Asian Stock Exchanges. Available at: http://www.feas.org. 
financial market systems allows for the creation of new financial products, increasing competition in the market and creating new investment opportunities. As a result, integration can lead to faster growth in the total volume of integrated markets compared to the growth of the total volume of individual markets. However, the integration capabilities of domestic markets are limited. At the current stage of market development, the process of integration with external markets is also of high importance. Integration of the exchange market in the EAEU countries can occur in almost all market segments. Integration opportunities exist both in the primary market and in the secondary market, both in the government and corporate securities markets.

Integration processes in the primary market can include the creation of integrated platforms for the initial placement of securities, access to which may be available to professional participants in the securities market of other countries of the EAEU. Additionally, it can include the creation of mechanisms for redirecting the applications of professional participants in the securities market of one country to professional market participants in the securities market of another country, and to their nation's local exchange market. In the first case, much more changes will be needed in national laws and other regulations governing the securities market. In the second case, the transaction costs associated with the execution of applications will increase. The introduction of integrated systems and mechanisms for redirecting applications in the primary market of government securities will provide an opportunity to ensure stable financing of the budget deficit with a parallel reduction in the costs of servicing the public debt. Despite the similarity and interconnectedness of the economies of the countries of the post-Soviet space, the economies of the EAEU countries have significant differences that lead to time lags (or even shifts) in economic cycles, the need for budget expenditures and changes in the size of budget revenues and budget deficits. Differences are mainly related to the structure of the economies of individual countries, as well as foreign economic relations. From the point of view of the dependence of the country's economy on energy prices, the countries of the EAEU may be divided into two groups: in Russia and Kazakhstan, revenues from energy carriers constitute a significant share of GDP, whereas in Armenia, Belarus and Kyrgyzstan, energy carriers do not play a significant role in the formation of the state budget. From the point of view of foreign economic relations, the countries of the EAEU can be divided into countries more integrated with (and dependent on) European markets (Armenia, Belarus) and countries more integrated with (and dependent on) Asian markets (the Russian Federation and Kazakhstan); these in turn also affects their exposure to different risks. Given the existence of such economic lags (shifts), the integration of the government securities market in the EAEU countries can help to increase the diversification of sources of financing the budget deficit, which in turn can contribute to ensuring the stability of budget deficit financing and the reduction of public debt servicing costs.

The introduction of integrated systems and mechanisms for redirecting applications in the primary market for corporate securities can increase the investment opportunities of the market, the mobility of capital and also the role of the securities market in financing investment projects. 
Integration processes in the secondary market can also include the creation of integrated trading platforms, access to which can be granted to the professional participants in the securities market from other countries of the EAEU and the creation of mechanisms for redirecting applications. The introduction of integrated systems and mechanisms for redirecting applications in the secondary securities market can help increase the liquidity of the securities market, increase competition and create a market value for securities.

\section{Conclusions}

The conducted studies show that the securities market in the EAEU countries has sufficient integration capabilities. As the above data show, the potential exists in all segments of the securities market, but more opportunities exist in the debt securities market. This is due to the fact that this segment of the market, unlike the equity market, is to some extent developed in almost all the countries of the EAEU. Deepening the integration processes in the securities market of the EAEU countries can have a positive impact on increasing the investment opportunities of the economy of the EAEU countries, which in turn can have a positive impact on GDP growth, reducing unemployment and improving the social status of the population. However, the creation of a single or integrated exchange market should be accompanied by the integration of the member states' depository, settlement and clearing systems and the synchronization of the regulatory and legal framework governing the securities market. Particular attention is required to study the problems associated with fixing and transferring property rights to the securities and protecting the interests of investors. Integrating the countries' depository, settlement and clearing systems may include the introduction of a nominal holding institution for central securities depositories and the establishment of correspondent relations between the central securities depositories in the EAEU countries. Thanks to the establishment of correspondent relations between the central securities depositories, it will be possible to ensure the recording and transfer of proprietary rights and other property rights to the securities, and to ensure the maximum protection of the interests of investors. For the development of integration processes both on the exchange market and between depository, settlement and clearing systems, the most important prerequisite is synchronization and, in the future, unification of the regulatory and legal framework governing the securities market. The main problems are connected with the fact that after the collapse of the Soviet Union, the development of the regulatory and legal framework in the territory of the former union republics took place in different ways. In this context, it is important to synchronize the regulatory framework governing the Russian and Armenian securities markets, despite the differences in the volumes of these markets. The importance of this process is conditioned by the fact that the regulatory framework governing the securities market of the Republic of Armenia is most synchronized with the legislation of the countries of the European Union and, in particular, with the regulatory and legal framework of the countries of the Baltic region. The creation of a synchronized regulatory and legal framework regulating the 
securities market can lay the foundation for the formation of a single integrated Eurasian securities market.

\section{References}

Baghdasaryan A.M. (2012) Peculiarities of Development of the Regulated Securities Market in the USA and the Russian Federation. Hayastan. Finances and Economics, no 9 (147), pp. 6-10.

Baghdasaryan A.M. (2013) The Ways of Development of the Securities Market in the Republic of Armenia. Yerevan: Nairi.

Bessarabova V.E. (2013) Razvitie fondovogo rynka kak faktora uskorenija rosta sovremennoj rossijskoj jekonomiki [Development of the Stock Market as a Factor for Accelerating the Growth of the Modern Russian Economy]. Ph.D. thesis. Moscow. (In Russian.)

Bolonin A.I. (2010) Metodologija razrabotki koncepcii regulirovanija finansovo-kreditnoj sistemy [Methodology for the Development of the Concept of Regulation of the Financial and Credit System]. Ph.D. thesis. Moscow. (In Russian.)

Dementiev V.E. (2009) Dlinnye volny jekonomicheskogo razvitija i finansovye puzyri [Long waves of economic development and financial bubbles]. Working paper no WP/2009/252. Moscow: CEMI RAS. (In Russian.)

Fabozzi F.J., Modigliani F.P., Jones F.J. (2009) Foundations of Financial Markets and Institutions (4th Edition). Prentice Hall.

Fedorova E.A. (2011) Finansovaja integracija fondovyh rynkov: teorija, metodologija i instrumentarij [Financial Integration of Stock Markets: Theory, Methodology and Tools]. Ph.D. thesis. Moscow. (In Russian.)

Gevorgjan V.M. (2013) Osnovnye puti provedenija pervichnogo publichnogo predlozhenija akcij v RA [The Main Ways of Conducting the Initial Public Offering of the Shares in the RA]. Ph.D. thesis. Yerevan. (In Russian.)

Glusheckij A.A. (2012) Konceptual'nye i prikladnye aspekty razmeshhenija jemissionnyh cennyh bumag (akcij) [Conceptual and Applied Aspects of the Placement of Equity Securities (shares)]. Ph.D. thesis. Moscow. (In Russian.)

Gorlovskaja I.G. (2010) Formirovanie metodologii i mehanizma regulirovanija uslug professional'nyh subjektov rynka cennyh bumag [Formation of Methodology and Mechanism of Regulation of Services of Professional Securities Market Entities]. Ph.D. thesis. Yerevan. (In Russian.)

Ilyas A.A. (2012) Razvitie finansovyh otnoshenij na rynkah kapitala Kazahstana v edinom jekonomicheskom prostranstve EvrAzJeS [Development of Financial Relations in the Capital Markets of Kazakhstan in the Single Economic Space of EurAsEC]. Ph.D. thesis. Moscow. (In Russian.)

Ilyin E.V. (2012) Mehanizmy i predely samoregulirovanija na finansovyh rynkah v razvityh stranah mira [Mechanisms and limits of self-regulation in financial markets in developed countries]. Ph.D. thesis. Moscow. (In Russian.)

Karev I.V. (2012) Finansirovanie investicij s ispol'zovaniem instrumentov fondovogo rynka /Financing of Investments Using Stock Market Instruments]. Ph.D. thesis. (In Russian.)

Kiselev M.V. (2010) Rossijskij rynok srochnyh finansovyh instrumentov: problemy i perspektivy razvitija [The Russian Market of Derivative Instruments: Problems and Development Prospects]. Ph.D. thesis. (In Russian.)

Korneev V.S. (2007) Tendencii razvitija institucional'nyh investorov na rossijskom rynke cennyh bumag [Trends in the Development of Institutional Investors in the Russian Securities Market]. Ph.D. thesis. (In Russian.)

Kozlov N.B. (2002) Formirovanie rynka cennyh bumag v postsocialisticheskih stranah [Formation of the Securities Market in Post-socialist Countries]. Moscow. (In Russian.)

Kudinova M.M. (2005) Rossijskij i zarubezhnye rynki cennyh bumag: problemy vzaimodejstvija [Russian and Foreign Securities Markets: Problems of Interaction]. Ph.D. thesis. (In Russian.) 
Margarjan L.A. (2013) Problemy povyshenija jeffektivnosti korporativnogo upravlenija (po materialam bankov RA) [Problems of Increasing the Effectiveness of Corporate Governance (based on the materials of banks of the Republic of Armenia]. Ph.D. thesis. (In Russian.)

Miller A.A. (2013) Razvitie regional'nogo rynka cennyh bumag [Development of the Regional Securities Market]. Ph.D. thesis. (In Russian.)

Mirkin Ya.M. (1995) Cennye bumagi ifondovyj rynok [Securities and the Stock Market]. Moscow: Perspektiva. P. 66, 99-100, 413. (In Russian.)

Mirkin Ya.M. (2002) Rynok cennyh bumag: Vozdejstvie fundamental'nyh faktorov, prognoz i politika razvitija [The Securities Market: The Impact of Fundamental Factors, Forecast and Development Policy]. Moscow: Financial Academy under the Government of the Russian Federation. (In Russian.)

Nijazbekova Sh.U. (2014) Razvitie fondovogo rynka v uslovijah formirovanija Edinogo jekonomicheskogo prostranstva [Development of the Stock Market in the Conditions of Formation of the Common Economic Space]. Ph.D. thesis. (In Russian.)

Pavelyeva E.A. (2013) Organizacionno-metodicheskoe obespechenie processa sek'juritizacii aktivov na rossijskom finansovom rynke [Organizational and Methodical Support of Asset Securitization in the Russian Financial Market]. Ph.D. thesis. (In Russian.)

Puchkov A.A. (2003) Depozitarnaja dejatel'nost' na rynke cennyh bumag Rossii [Depository activity on the Russian securities market]. Ph.D. thesis. (In Russian.)

Rubcov B.B. (2000) Mirovye fondovye rynki: sovremennoe sostojanie i zakonomernosti razvitija [World Stock Markets: The Current State and Patterns of Development]. Moscow: Financial Academy under the Government of the Russian Federation.

Rzhevskaja T.G. (2012) Razvitie finansovoj sistemy i mehanizmy ejo regulirovanija v uslovijah rynochnoj transformacii [Development of the Financial System and Mechanisms for its Regulation under Conditions of Market Transformation]. Ph.D. thesis. (In Russian.)

Salnazarjan A.B. (2003) Investicionnye funkcii i jeffektivnost' rynka cennyh bumag [Investment Functions and the Efficiency of the Securities Market (on the example of the RA)]. Ph.D. thesis. (In Russian.) Semernina Ju.V. (2012) Teorija i metodologija obligacionnogo finansirovanija hozjajstvu-jushhih subjektov na rossijskom rynke cennyh bumag [Theory and methodology of bond financing of economic entities in the Russian securities market]. Ph.D. thesis. (In Russian.)

Shalisko V.A. (2013) Modernizacija infrastruktury fondovogo rynka Rossii kak uslovie formirovanija nadnacional'nogo finansovogo centra [Modernization of the Infrastructure of the Russian Stock Market as a Condition for the Formation of a Supranational Financial Center]. Ph.D. thesis. (In Russian.)

Stanik N.A. (2013) Krizisy na rynke cennyh bumag: harakternye cherty i metody rannej identifikacii [Crises in the Securities Market: Characteristic Features and Methods of Early Identification]. Ph.D. thesis. (In Russian.)

Stacenko V.V. (2012) Razvitie individual'nogo investirovanija na rossijskom fondovom rynke [Development of individual investment in the Russian stock market]. Ph.D. thesis. (In Russian.)

Tereshhenko N.N. (2011) Sek'juritizacija i ee rol' v finansirovanii investicionnyh proektov [Securitization and its Role in the Financing of Investment Projects]. Ph.D. thesis. (In Russian.)

Tsarikhin K.S. (2008) Fondovyj rynok i mir [The Stock Market and the World]. Available at: http://www. mirkin.ru/_docs/rinokimir_intro.pdf (accessed 03 October 2017). (In Russian.)

Vahrushin I.V. (2009) Rynok cennyh bumag KNR: sostojanie, razvitie, perspektivy [The Securities Market of China: State, Development, Prospects]. Ph.D. thesis. (In Russian.)

Vilkova T.B. (2007) Konflikty interesov pri osushhestvlenii brokerskoj dejatel'nosti na rynke cennyh bumag i metody ih razreshenija [Conflicts of Interest in the Implementation of Brokerage Activities in the Securities Market and Methods for their Resolution]. Ph.D. thesis. (in Russian).

Zaharov A.V., Kirichenko D.A., Chelmodeeva E.V. (2002) Valjutnye i universal'nye birzhi XXI veka kak antikrizisnyj mehanizm finansovogo rynka [Currency and Univeral Exchanges of the 21st Century as an Anti-crisis Mechanism of the Financial Market]. Ph.D. thesis. (In Russian.) 


\title{
Проблемы развития и интеграции рынка ценных бумаг в странах ЕАЭС 1
}

\author{
А.А. Баядян, А.М. Багдасарян
}

Баядян Ашот Акопович - д.э.н., профессор, заведующий кафедрой финансов и кредита экономического факультета Национального аграрного университета Армении; Республика Армения, Ереван, 0009, ул. Терьяна, д. 74; E-mail: info@anau.am

Багдасарян Арег Меружанович - к.э.н., доцент кафедры финансов и кредита экономического факультета Национального аграрного университета Армении; Республика Армения, Ереван, 0009, ул. Терьяна, д. 74; E-mail: aregbag@gmail.com

Статья посвящена изучению проблем развития и интеграции рынка ценных бумаг в государствах - членах Евразийского экономического союза (ЕАЭС). Рассматриваются настоящее состояние, возможности и проблемы развития рынка ценных бумаг, и в частности биржевого рынка. Развитие и интеграция рынка ценных бумаг - важные факторы, влияющие на потенциал развития экономики и устойчивого экономического роста в странах ЕАЭС.

Предметом анализа настоящего исследования являются проблемы развития и интеграции рынка ценных бумаг в странах ЕАЭС.

Авторыприходятквыводу, чторынокценныхбумагв странах ЕАЭСобладает достаточными интеграционными возможностями. Потенциал существует во всех сегментахрынка ценных бумаг, однако более широкие возможности на рынке долговых ценных бумаг. Углубление интеграционных процессов на рынке ценных бумаг ЕАЭС может оказать положительное воздействие на увеличение инвестиционных возможностей экономики этих стран, что в свою очередь может содействовать увеличению темпов роста валового внутреннего продукта, сокращению безработицы и улучшению социального положения населения. Однако создание единого или интегрированного биржевого рынка должно сопровождаться интеграционными процессами депозитарных и расчетно-клиринговых систем и синхронизацией нормативно-правовой базы, регулирующей рынок ценных бумаг. Особого внимания требует исследование проблем, связанных с фиксированием и передачей имущественных прав на ценные бумаги и защитой интересов инвесторов. Интеграционные процессы депозитарных и расчетно-клиринговых систем могут включать внедрение института номинального держателя для центральных депозитариев и установление корреспондентских отношений между иентральными депозитариями ценных бумаг стран ЕАЭС. Для развития интеграционных процессов как на биржевом рынке, так и между депозитарными и расчетно-клиринговыми системами важнейшей предпосылкой является синхронизация, а в дальнейшем - унификация нормативно-правовой базы, регулирующей рынок ценных бумаг.

Ключевые слова: рынок ценных бумаг; биржевой рынок; инфраструктура рынка ценных бумаг

Для цитирования: Баядян А.А., Багдасарян А.М. Проблемы развития и интеграции рынка ценных бумаг в странах ЕАЭС // Вестник международных организаций. 2017. Т. 12. № 4. С. 91-108. DOI: $10.17323 / 1996-7845-2017-04-91$

\section{Источники}

Бессарабова В.Е. (2013) Развитие фондового рынка как фактора ускорения роста современной российской экономики: дисс. ... канд. экон. наук. Москва.

Болонин А.И. (2010) Методология разработки концепции регулирования финансово-кредитной системы: дисс. ... докт. экон. наук. Москва.

Вахрушин И.В. (2009) Рынок ценных бумаг КНР: состояние, развитие, перспективы: дисс. ... канд. экон. наук. Москва.

Вилкова Т.Б. (2007) Конфликты интересов при осуществлении брокерской деятельности на рынке ценных бумаг и методы их разрешения: дисс. ... канд. экон. наук. Москва.

\footnotetext{
${ }^{1}$ Статья поступила в редакцию в сентябре 2016 г.
} 
Геворгян В.М. (2013) Основные пути проведения первичного публичного предложения акций в РА: дисс. ... канд. экон. наук. Ереван.

Глушецкий А.А. (2012) Концептуальные и прикладные аспекты размещения эмиссионных ценных бумаг (акций): автореф. дисс. ... докт. экон. наук. Москва.

Горловская И.Г. (2010) Формирование методологии и механизма регулирования услуг профессиональных субъектов рынка ценных бумаг: дисс. ... докт. экон. наук. Екатеринбург.

Дементьев В.Е. (2009) Длинные волны экономического развития и финансовые пузыри: препринт WР/2009/252. М.: ЦЭМИ РАН.

Захаров А.В., Кириченко Д.А., Челмодеева Е.В. (2002) Валютные и универсальные биржи XXI века как антикризисный механизм финансового рынка. 2-е изд., перераб. и доп. Москва.

Ильин Е.В. (2012) Механизмы и пределы саморегулирования на финансовых рынках в развитых странах мира: дисс. ... канд. экон. наук. Москва.

Ильяс А.А. (2012) Развитие финансовых отношений на рынках капитала Казахстана в едином экономическом пространстве ЕврАзЭС: автореф. дисс. ... докт. экон. наук. Москва.

Карев И.В. (2012) Финансирование инвестиций с использованием инструментов фондового рынка: дисс. ... канд. экон. наук. Волгоград.

Киселев М.В. (2010) Российский рынок срочных финансовых инструментов: проблемы и перспективы развития: автореф. дисс. ... докт. экон. наук.

Козлов Н.Б. (2002) Формирование рынка ценных бумаг в постсоциалистических странах. Москва.

Корнеев В.С. (2007) Тенденции развития институциональных инвесторов на российском рынке ценных бумаг: дисс. ... канд. экон. наук. Москва.

Кудинова М.М. (2005) Российский и зарубежные рынки ценных бумаг: проблемы взаимодействия: дисс. ... канд. экон. наук. Москва.

Маргарян Л.А. (2013) Проблемы повышения эффективности корпоративного управления (по материалам банков РА): дис. ... канд. экон. наук. Ереван.

Миллер А.А. (2013) Развитие регионального рынка ценных бумаг: дисс. ... канд. экон. наук. Омск.

Миркин Я.М. (1995) Ценные бумаги и фондовый рынок. М.: Перспектива. С. 66, 99-100, 413-440.

Миркин Я.М. (2002) Рынок ценных бумаг: воздействие фундаментальных факторов, прогноз и политика развития. М.: Финансовая академия при правительстве РФ.

Ниязбекова Ш.У. (2014) Развитие фондового рынка в условиях формирования Единого экономического пространства: дисс. ... канд. экон. наук. Москва.

Павельева Е.А. (2013) Организационно-методическое обеспечение процесса секьюритизации активов на российском финансовом рынке: дисс. ... канд. экон. наук.

Пучков А.А. (2003) Депозитарная деятельность на рынке ценных бумаг России: дисс. ... канд. экон. наук. Москва.

Ржевская Т.Г. (2012) Развитие финансовой системы и механизмы ее регулирования в условиях рыночной трансформации: автореф. дисс. ... докт. экон. наук. Москва.

Рубцов Б.Б. (2000) Мировые фондовые рынки: современное состояние и закономерности развития. М.: Финансовая академия при правительстве РФ.

Салназарян А.Б. (2003) Инвестиционные функции и эффективность рынка ценных бумаг (на примере РА): автореф. дисс. ... докт. экон. наук. Ереван.

Семернина Ю.В. (2012) Теория и методология облигационного финансирования хозяйствующих субъектов на российском рынке ценных бумаг: автореф. дисс. ... докт. экон. наук.

Станик Н.А. (2013) Кризисы на рынке ценных бумаг: характерные черты и методы ранней идентификации: дисс. ... канд. экон. наук. Москва.

Стаценко В.В. (2012) Развитие индивидуального инвестирования на российском фондовом рынке: автореф. дисс. ... канд. экон. наук. Ростов-на-Дону. 
Терещенко Н.Н. (2011) Секьюритизация и ее роль в финансировании инвестиционных проектов: дисс. ... канд. экон. наук. Москва.

Федорова Е.А. (2011) Финансовая интеграция фондовых рынков: теория, методология и инструментарий: автореф. дисс. ... экон. наук. Москва.

Царихин К.С. (2008) Фондовый рынок и мир. Режим доступа: http://www.mirkin.ru/_docs/rinokimir_ intro.pdf (дата обращения: 03.10.2017).

Шалиско В.А. (2013) Модернизация инфраструктуры фондового рынка России как условие формирования наднационального финансового центра: автореф. дисс. ... канд. экон. наук. СПб.

Baghdasaryan A.M. (2012) Peculiarities of Development of the Regulated Securities Market in the USA and the Russian Federation // Hayastan. Finances and Economics. No. 9 (147). P. 6-10.

Baghdasaryan A.M. (2013) The Ways of Development of the Securities Market in the Republic of Armenia, Monograph. Yerevan: Nairi.

Fabozzi F.J., Modigliani F.P., Jones F.J. (2009) Foundations of Financial Markets and Institutions (4th ed.). Prentice Hall. 